
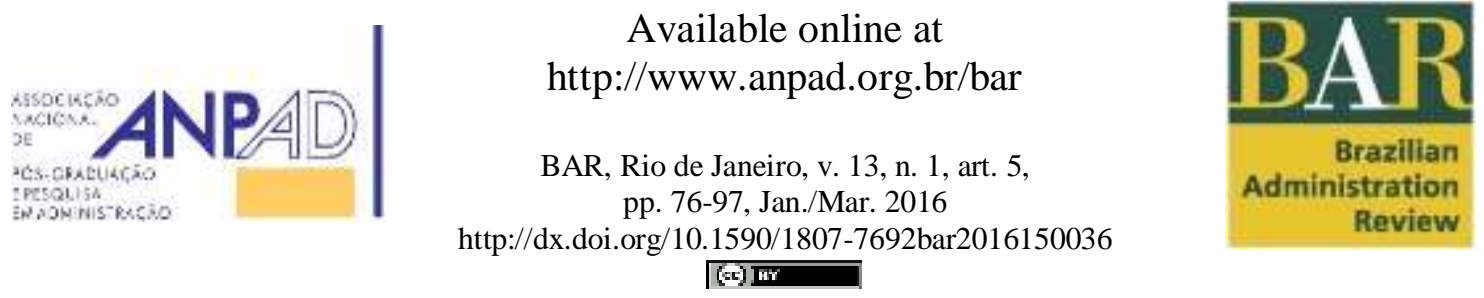

\title{
Corwin-Schultz Bid-ask Spread Estimator in the Brazilian Stock Market
}




\begin{abstract}
This paper tests the validity of the Corwin-Schultz bid-ask spread estimator in the Brazilian stock market. The Corwin-Schultz estimator arises as an easy way to compute asymmetric information throughout daily high and low stock prices for estimating overnight and non-negative adjusted spreads. The sample consisted of Ibovespa firms from 1986 to 2014 and was analysed with time series econometrics. The findings show that the measures of spread have stationarity properties, allowing for forecasting in a period of lagged variables, besides having the property of time-varying cointegration with market-to-book ratio, debt on equity, size and return and also presenting sensibility to different periods, industries and listing segments. Thus, the Corwin-Schultz bid-ask spread estimator seems to be a valid and reliable measure for forecasting aggregate-data variables through the weighted average of firm-level variables.
\end{abstract}

Key words: Corwin-Schultz bid-ask spread estimator; asymmetric information; market microstructure; time varying cointegration. 


\section{Introduction}

Comprehending how information is obtained and disseminated is essential to understand how economies function (Rosser, 2003) as well as how it affects price movements (Cuthbertson \& Nitzche, 2004; Muth, 1961).

Information asymmetry occurs when one trader has more or better information than another, and this asymmetry influences market equilibrium (Akerlof, 1970) the informed traders' orders bring information to the stock prices, improving the information's quality of other traders, throughout the signalling issues (Spence, 1973), thus showing that competition in markets with imperfect information is more complex than assumed in classical economics. This complexity is because competitors may limit their customers' purchases and competitive equilibria are not Pareto optimal (Rothschild \& Stiglitz, 1976). In particular, for stock markets, as Grossman and Stiglitz (1980) show, the only way for informed traders to earn abnormal returns is to take better positions than uninformed ones, because trade activity causes private information to influence prices, although imperfectly.

However, asymmetric information occurs in the trading activity of stock markets along with order processing and inventory holding costs, and sometimes it could be difficult to distinguish between them, but the effects of adverse selection/asymmetric information have been found to be a significant part of the spread between bid-ask quotes (Huang \& Stoll, 1997). The behaviour of these components is quite different as well. Adverse selection has been found to increase when earnings announcements are expected, but order processing and inventory holding have been found to decrease (Krinsky \& Lee, 1996).

Minardi, Sanvicente, and Monteiro (2006) showed the absence of order processing and inventory holding costs and the presence of asymmetric information costs in the Brazilian stock market. Therefore, for the present study, we directly treat bid-ask spread as asymmetric information.

Furthermore, this study considers that asset prices are driven by equality between purchase and sales flows rather than demand and supply issues. Therefore, we use an information-based model, focusing on asymmetric information and assuming that market makers cannot observe the origin of orders (Bailey, 2005).

In this study, we investigate the validity of the bid-ask spread estimator (Corwin \& Schultz, 2012a) as an easy-to-compute and alternative measure of asymmetric information in the Brazilian stock market. The relevance of this type of research model increases because the high-frequency data used to obtain another measure of asymmetric information (pin score) have only been recently available (Easley, Hvidkjaer, \& O'Hara, 2002; Martins \& Paulo, 2013).

Minardi et al. (2006) developed and tested a measure for bid-ask spread in the Brazilian stock market from 1998 to 2003. Their findings showed that bid-ask spread is correlated negatively with liquidity and positively with return. They analysed data of the biggest firms using correlation and ordinary least squares (OLS) estimation methods.

In this study, we analyse the aggregate daily high and low stock price data of the most traded shares on the Brazilian stock market from 1986 to 2014. The Corwin-Schultz measures of asymmetric information are stationary and can be forecast using single-equation dynamic modelling (Granger, 1981). The aggregate data are obtained from the weighted average of the firm-level Ibovespa components' data for the second quarter of 2014.

The results are consistent with those of other studies examining the same market (Martins, Paulo, \& Albuquerque, 2013) and market microstructure theory (Easley et al., 2002). The measures are sensitive to different periods, industries, and listing segments and have a time-varying cointegration vector with firm-level characteristics. 
The remainder of this paper is structured as follows. The next section presents the theoretical framework comprising the market microstructure theory, the probability of information-based trading measure (PIN) score, and Corwin-Schultz issues. The third section describes the sample and the timeseries techniques applied. The fourth section presents and discusses the findings, and the final section presents the main implications and concluding remarks.

\section{Theoretical Framework}

\section{Market microstructure}

Hasbrouck (2007) identified the electronic limit order book, asymmetric information, and linear time-series analysis as the prominent trading approaches used to study financial securities or market microstructure. Madhavan (2000) conceptualizes market microstructure as the financial area pertaining to the process by which the latent demands of investors ultimately translate into transactions. The author clarifies the importance of market microstructure and informational economics and identifies the links between the former and the fields of investment, financing, and capital structure. For market microstructure theory, asset prices need not reflect the full-information expectation values due to a variety of frictions driven by the rapid structural, technological, and regulatory changes affecting the securities industry world-wide. Hasbrouck (2007) argues that only the minute or second horizon is relevant from the point of view of microstructure perspective of stock prices. He also alleges there are two main types of asymmetric information models: sequential trade models (trader randomly selected) and strategic trade models (single informed agent trades multiple trades and reveals some private information).

Roll (1984) presented a method to infer the effective bid-ask spread that requires only the securities time-series' prices, assuming market efficiency and stationarity of observed price changes. The effective bid-ask spread can be estimated with the Equation Spread $=2 \sqrt{-\operatorname{cov}}$, where 'cov' is the first-order serial covariance of price changes. This method came to be known as the Roll serial covariance bid-ask estimator, following Harris (1990), who examined its statistical properties and argued that Roll's method has a small sample estimator bias whereas French and Roll's (1986) adjustedvariance estimator is unbiased but noisy. The latter method was proposed by French and Roll (1986) while examining the greater variances in trading hour than non-trading hour returns. Glosten and Milgron (1985) believed that bid-ask spread implies a divergence between the observed and realizable returns and that the observed returns are approximately the realizable returns plus what the uninformed anticipate when losing to insiders. Glosten and Harris (1988) proposed, estimated, and cross-validated a two-component asymmetric information spread model, while decomposing the bid-ask spread into asymmetric information and inventory costs components. They found the spread to be a function of trade size.

Hasbrouck (1988) examined the effects of asymmetric information and inventory control on the relation between trades and quote revisions, and found substantial information on trade and strong evidence that large trades conveyed more information than small trades. Hasbrouck (1996) further examined the information on automated orders by using an econometric model capturing the joint behaviour of automated orders and the return on stock index futures, and found that orders contain information useful in predicting stock returns beyond the information contained in the reported trades. In another paper, Hasbrouck (1999) proposed a dynamic bid-ask quotes model incorporating the microstructure effects arising from the manner in which security is traded, such as the stochastic cost of market-making, discreteness, and clustering, using Gibbs sampler as a convenient estimation vehicle.

Hasbrouck and Seppi (2001) found that bid-ask spread and quote sizes help explain the time variation in trade impacts, and that existing common factors can explain the common variation in signed and absolute returns. Hasbrouck and Saar (2009) examined a limit order book during a month and 
observed that about $37 \%$ of the limit orders are cancelled within two seconds of submission, suggesting the traders search for liquidity.

Roll and Subrahmanyam (2010) found that competition among market makers lead to an increasing right-skewed distribution of bid-ask spreads and such spreads are associated to institutional holdings and the quantity of analysts that follow the company. Roll, Schwartz, and Subrahmanyam (2014) found a strong association among options trading, short interest rate, term structure and credit spreads, concluding the relevance of informational role of options.

Hasbrouck and Saar (2013) proposed the RunsInProcess, a measure of low-latency activity used to investigate the impact of high-frequency trading on the market environment using publicly available data, suggesting that the millisecond environment constitutes a fundamental change from the manner in which stock markets operated.

\section{PIN score}

Easley, Kiefer, and O’Hara (1997) developed the PIN, which is now standard in the literature. This measure uses the price, lagged price, and number of buys and sells to identify the importance of buy and sell trade in model specification and show how such a model can be used in a well-defined statistical framework to guide empirical work (Easley, Kiefer, \& O'Hara, 1997). The paper followed Easley and O'Hara's (1992) findings that trade time affects prices, with the time between trades affecting the spreads of security prices and volume affecting the speed of price adjustment. The definition of trade direction followed Lee and Ready's (1991) algorithm.

Easley, Hvidkjaer, and O’Hara (2002) used Easley et al.'s (1997) PIN model to incorporate obtained estimates into a Fama-French asset-pricing framework, and found that such information does affect asset pricing. Hasbrouck (1991) suggested the asymmetric information is negatively associated to the size of companies and some interactions of stock trades and quote revisions can be specified as a vector autoregressive system. Easley and O`Hara (1991) showed that the market maker who knows the type and composition of trades can set larger spreads and adjust prices faster than if price-contingent orders were not allowed, and confirmed the important policy implications of distinction between variance and episodic price volatility. Blume, Easley and O'Hara (1994) found quality information is provided by volume, beyond investigating the association among volume, precision and stock prices and how informational sequences of volume and prices are. They concluded that technical analysis arises as a natural component of agents' learning processes. Easley, Kiefer, O'Hara, and Paperman (1996) found that the probability of information-based trading is lower for high-volume stocks and provided evidence of the economic effect of information-based trading on spreads.

Easley, O'Hara, and Srinivas (1998) developed a model where informed traders trade in equity or option markets and confirmed that option volumes are useful for forecasting stock price. Dufour and Engle (2000) tested and estimated the role played by waiting time between consecutive transactions in the process of price formation using Hasbrouck's (1991) vector autoregressive (VAR) system, and found a negative association between waiting time, price impact of trade, speed of price adjustment to traderelated information, and the autocorrelation of signed trades. O'Hara (2003) developed an asymmetric information asset-pricing model incorporating the transaction costs of liquidity and risks of price discovery and examined the implications of market microstructure for asset pricing. Easley and O'Hara (2004) investigated the role of information in a firm's cost of capital and concluded that investors demand a higher return on stocks with greater private information. Agarwal and O'Hara (2006) found that the PIN drives the capital structure, with companies having higher extrinsic asymmetric information more likely to increase their leverage.

Hasbrouck (2007, p. 42) argues "that agents always face the same spread, which represents the costs of security necessary for trading in securities". Chan, Mankveld, and Yang (2008) constructed information asymmetry measures for equity pricing in the local A-share and foreign B-share Chinese markets following Easley et al. (1997), and found that they explain a significant portion of the crosssectional variation in B-share discounts even after controlling for other factors. 
Martins and Paulo (2013) applied Easley et al.'s (2002) PIN model to estimate the asymmetric information level of the Brazilian stock market and its association with liquidity. They found an average PIN of 0.249 for 229 listed firms from 2010 to 2011 and a negative association between liquidity and PIN only for common stocks with high liquidity. In another paper (Martins \& Paulo, 2014), the authors found a positive relationship between the PIN and risk, return, and liquidity of shares as well as cost of equity and size of companies and a negative relationship between the PIN and abnormal returns of shares. Martins, Paulo, and Albuquerque (2013) estimated the PIN in relation to stock returns and found a negative association between corporate governance and information asymmetry and a positive association between the PIN and stock returns. Finally, Girão, Martins, and Paulo (2014) found an average PIN of 0.229 in the Brazilian stock market, but no significant association between the PIN and an accounting variables valuation model.

\section{The Corwin-Schultz bid-ask spread estimator}

Corwin and Schultz (2012a) developed a bid-ask spread estimator from daily high and low prices to measure the bid-ask spread of shares, using an easy calculation method. The estimator is based on two assumptions. First, the daily high prices are typically buyer initiated and low prices are seller initiated, and therefore the ratio of high-to-low prices for a day reflects both the fundamental volatility of stock and its bid-ask spread. Second, the volatility component of the high-to-low price ratio increases proportionately with the length of trading interval whereas the component due to bid-ask spreads does not. Throughout the simulations constructed under realistic conditions, as the authors argue, the correlation between the high-low spread estimates and true spreads is about 0.9 and the standard deviation of the high-low spread estimates is only one-half of the standard deviation of the estimates obtained from Roll's (1984) covariance spread estimator. The Corwin-Schultz bid-ask spread estimator is presented in equation (1) below, where $S$ is the spread; e is the mathematical constant (e basis) of x; $\alpha$ is as shown in (2), $\beta$ as in shown (3), and $\gamma$ as shown in (4); and $\mathrm{H}$ and $\mathrm{L}$ denote the observed high and low stock prices, respectively.

$$
\begin{aligned}
& S=\frac{2\left(e^{\alpha}-1\right)}{1+e^{\alpha}} \\
& \alpha=\frac{\sqrt{2 \beta}-\sqrt{\beta}}{3-2 \sqrt{2}}-\sqrt{\frac{\gamma}{3-2 \sqrt{2}}} \\
& \beta=E\left\{\sum_{j=0}^{1}\left[\ln \left(\frac{H_{t+j}^{0}}{L_{t+j}^{0}}\right)\right]^{2}\right\} \\
& \gamma=E\left\{\sum_{j=0}^{1}\left[\ln \left(\frac{H_{t, t+1}^{0}}{L_{t, t+1}^{0}}\right)\right]^{2}\right\}
\end{aligned}
$$

Variable (2) represents the difference between the adjustments of a single day and a 2-day period, (3) represents the daily high and low price adjustments to the high price, and (4) represents a 2-day period high and low price adjustments. Corwin and Schultz (2012a) posit that the estimator of (1) is easy to compute and that it does not require the researcher to successively iterate estimates of the spread to get the correct value. They have provided an electronic example to confirm the proposition.

Corwin and Schultz (2012b) tested their bid-ask estimator on individual stocks of 11 countries (Hong Kong, India, Korea, Japan, Italy, France, Belgium, Sweden, the United Kingdom, Brazil, and New Zealand), and have provided estimates of the U.S. stock market and other useful applications, examples, and notes. Maskara and Mullineaux (2011) computed the Corwin-Schultz bid-ask spread (2012a) and other measures to examine the abnormal announcement returns of loans and in general did not find significant association between returns and loan announcements. However, Karstanje, Sojli, Tham, and Wel (2013) found liquidity timing leading to tangible economic gains when comparing five different liquidity measures, including the Corwin and Schultz (2012a) measure. Lin (2014) modified the Corwin and Schultz (2012a) model to analyse the estimation accuracy of the high-low spread 
estimator and found that its performance depended on the size of the true spread, level of transaction frequency, and degree of volatility, and concluded that more empirical research is still needed to gain further evidence on the analysis. Zhang, Yang, Su, and Zhang (2014) tried to validate the Corwin and Schultz (2012a) method to predict the returns from 1926 to 2010 for the U.S. ordinary common stocks, and found the bid-ask measure lacking significantly as liquidity measure to predict returns. Cerqueira and Pereira (2014) provided evidence on the association between quality of financial reporting and information asymmetry in Europe, using discretionary accruals as a proxy for quality of financial reporting and the Corwin and Schultz (2012a) bid-ask spread estimator to measure information asymmetry, and found this measure more efficient than the closing bid-ask spread.

The PIN score reflects the probability of trading under private information. Consequently, the PIN probability price often equals the abnormal returns of informed traders. Corwin and Schultz's bidask spread estimator reflects the same abnormal return, but on the highest and lowest share prices instead of all trades of a day. Therefore, the PIN score and Corwin-Schultz bid-ask spread estimator figures can be directly compared. To reinforce this fact, note that the PIN score and Corwin-Schultz estimator figures give only the asymmetric information in markets without the order processing and inventory holding costs (Minardi, Sanvicente, \& Monteiro, 2006).

\section{Methodology}

In this study, we analyse the reliability and validity (Bryman, 2012) of the alternative asymmetric information measure proposed by Corwin and Schultz (2012a) for the Brazilian stock market. Here, reliability means the stability of coefficients (the absence of abrupt structural breaks) and validity refers to the forecast of a measure (Bryman, 2012). The augmented Dickey-Fuller (ADF) and single-equation dynamic modelling series (Dickey \& Fuller, 1979, 1981; Granger, 1981, 2010) were used, instead of Cronbach's alpha (Cronbach \& Shavelson, 2004), to assess the stability and forecast of measures, owing to the possible violation of several assumptions (Gu, Little, \& Kingston, 2013).

Brazil is an appropriate emerging country for analysing asymmetric information, considering its stock market has been reformed since 2002 (including its accounting standards). Its stock market has provided intraday trading data only for the last decade. Thus, Brazil can be considered suitable to research the new measure of asymmetric information for testing several financial theories.

The $\alpha, \beta$ and $\gamma$ estimates (equations 2, 3, and 4) of the Corwin and Schultz (2012a) model have been computed on the daily high and low stock prices of the constituents of Ibovespa (the Brazilian stock market weighted average of a theoretical portfolio). This index represents the shares of 68 mosttraded Brazilian listed companies in the second quarter of 2014 from 2 January 1986 to 2 June 2014. The sample considers only the actual level of asymmetric information in the Brazilian stock market, and not the risk of survival or other sample biases; furthermore, the true high and low prices of infrequently traded stocks are not considered (Corwin \& Schultz, 2012a). Following Corwin and Schultz (2012b), the resulting estimates (S_2 and S_0) are adjusted for overnight price changes and non-negative results.

The data have been aggregated by weighted average of each share on the index, allowing for proper application of time-series techniques. All data were updated up to the second quarter of 2014 based on consumer price index to mitigate inflationary effects. The sample was intended to be wide as possible to avoid the bias of rejection of cointegration null (Timmermann, 1995). To check for robustness of the measures, we divide S_2 and S_0 into different periods, firm level industries, and listing segments. We then test the measures for time-varying cointegration with the restricted variables obtained from combining the Chebyshev time polynomials (Bierens \& Martins, 2010) and the variables related to asymmetric information, such as market-to-book ratio (M/B) for growth opportunity set, debt on equity (D/E) for leverage, and size (SIZE) and stock market return (RETURN) for evolution of stock prices. While the exchange rate effects on asymmetric information of the Brazilian stock market could not be directly computed, the analysis of different periods tried to capture some of their consequences. 


\section{Results and Discussion}

\section{S_2 and S_0}

Variables S_2 and S_0 represent Corwin and Schultz's (2012b) overnight and non-negative adjusted bid-ask spread estimator respectively. The average daily spreads for S_2 and S_0 are 0.006 and 0.016 , and these lead to average monthly spreads of 0.13 and 0.34 , respectively (see Table 1 ). While the average monthly value of 0.249 is almost consistent with that of Martins and Paulo (2013), the monthly average for $2010-2011$ is higher.

Table 1

\section{Descriptive Statistics}

\begin{tabular}{cccccc}
\hline Variable & N. Obs. & Min. & Mean & Max. & Std. Dev. \\
\hline$\alpha$ & 114 & -0.0220 & 0.0065 & 0.0308 & 0.0100 \\
$\beta$ & 114 & 0.0007 & 0.0035 & 0.0153 & 0.0028 \\
$\gamma$ & 114 & 0.0007 & 0.0034 & 0.0161 & 0.0029 \\
S_2 & 114 & -0.0220 & 0.0065 & 0.0308 & 0.0100 \\
S_0 & 114 & 0.0068 & 0.0168 & 0.0419 & 0.0055 \\
S_2_Month & 114 & -0.4410 & 0.1351 & 0.6383 & 0.2050 \\
S_0_Month & 114 & 0.1512 & 0.3445 & 0.8669 & 0.1131 \\
\hline
\end{tabular}

Note. The table presents the descriptive statistics of the Corwin, S. A., \& Schultz, P. (2012a). A simple way to estimate bid and ask spreads from daily high and low prices. The Journal of Finance, 67(2), 719-759. doi: 10.1111/j.15406261.2012.01729.x, model's variables $\alpha, \beta$, and $\gamma$, which have been presented in equations (2), (3), and (4); $\mathrm{S} \_2$ is the pure spread and S_0 the non-negative spread, and both are adjusted to overnight returns. Source: The author.

The average S_2 and S_0 estimate is consistent with the Corwin and Schultz (2012b) estimate of S_0 for Brazil from 1993 to 2007 (0.0131). These are consistent with Minardi et al.'s (2006) results, which varied from 0.0131 to 1.1369 depending on the frequency. A comparison of these results shows that $\mathrm{S} \_2$ and $\mathrm{S} \_0$ have properties similar to other asymmetric information measures, as pointed out by Karstanje et al. (2013). It also confirms Hasbrouck's (2007) proposition that asymmetric information and linear time-series analysis are prominent market microstructure topics.

The spreads were higher for either S_2 or S_0 during the 2008 financial crisis. Minardi et al. (2006) found different spreads for volume and turnover, which is consistent with the changes observed in $\mathrm{S} \_2$ and $\mathrm{S} \_0$ for the financial crisis period.

The behaviour of asymmetric information in Brazil is presented in Figures 1 and 2, to complement the descriptive statistics. Figure 1 presents the $S \_2$ values for the analysed period. The maximum and minimum values can be easily detected, whereas the range (-0.02 to 0.03) and slope suggest that $\mathrm{S} \_2$ could be stationary with a trend. Stationarity is suggested for $\mathrm{S} \_0$ as well, which is presented in Figure 2. 


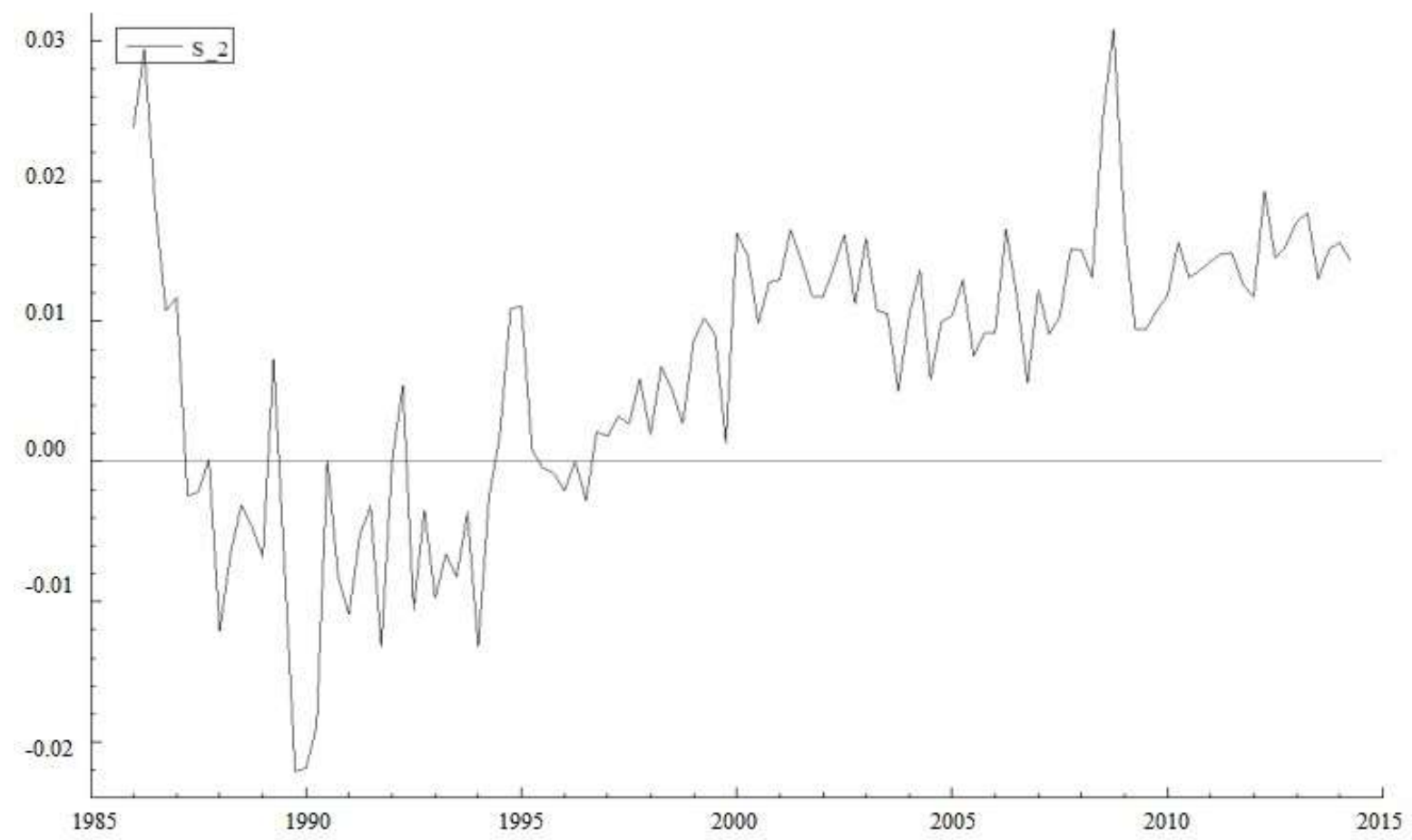

Figure 1. The Corwin-Schultz Spread in the Brazilian Stock Market

The figure presents the time-series of the pure and overnight return-adjusted spread of the Corwin, S. A., \& Schultz, P. (2012a). A simple way to estimate bid and ask spreads from daily high and low prices. The Journal of Finance, 67(2), 719-759. Retrieved from http://iawltxhtml.ivo-welch.info/sample-fame-3/cs.pdf. doi: 10.1111/j.1540-6261.2012.01729.x, model for the Brazilian stock market. Source: The author.

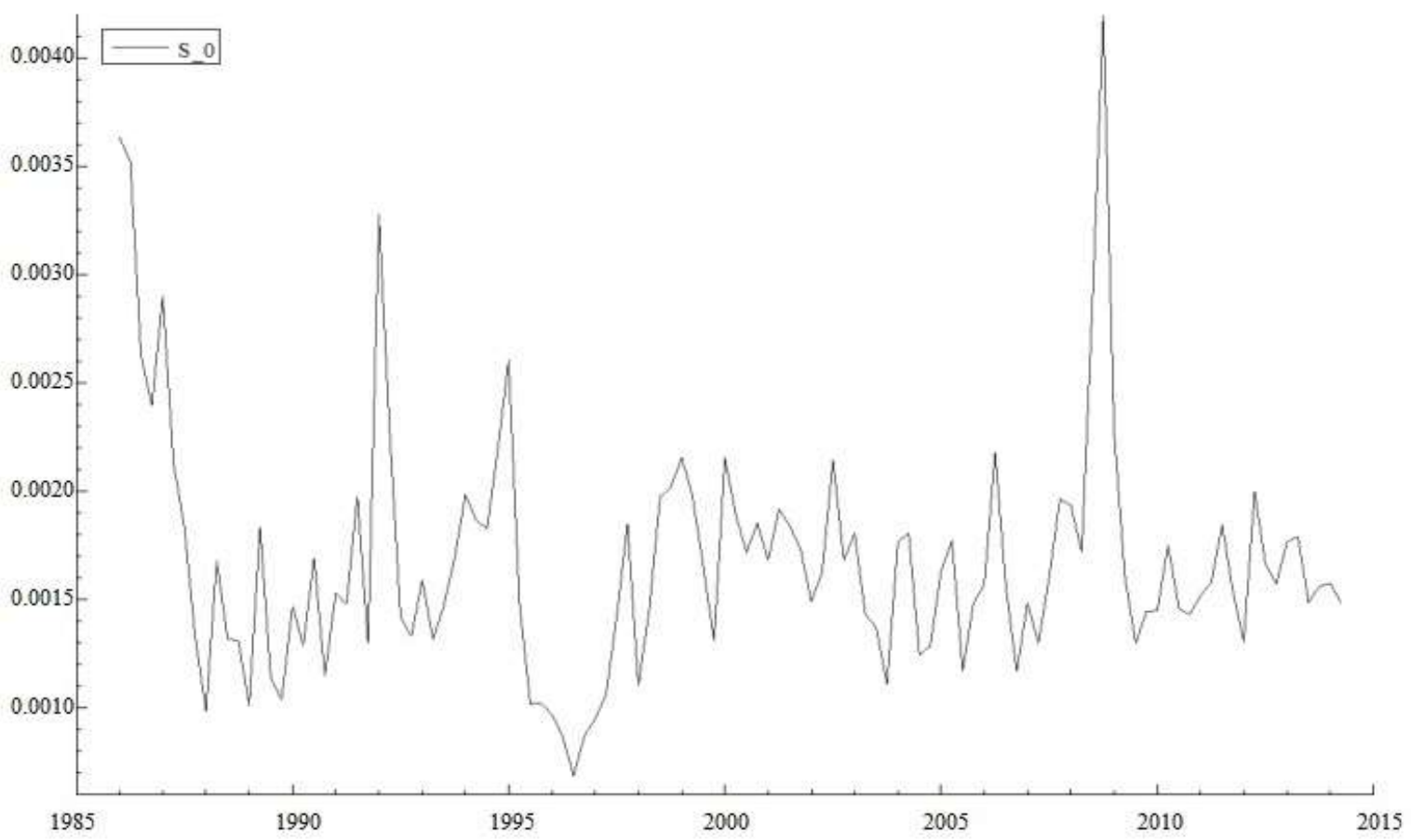

Figure 2. The Corwin-Schultz Non-negative Spread in the Brazilian Stock Market

The figure presents the time-series of the non-negative and overnight return-adjusted spread of the Corwin, S. A., \& Schultz, P. (2012a). A simple way to estimate bid and ask spreads from daily high and low prices. The Journal of Finance, 67(2), 719759. Retrieved from http://iawltxhtml.ivo-welch.info/sample-fame-3/cs.pdf. doi: 10.1111/j.1540-6261.2012.01729.x, model for the Brazilian stock market. Source: The author. 
The stationarity of S_2 and S_0 have been confirmed in unit root tests (Dickey \& Fuller, 1979, 1981), with strong statistical significance in the three periods of lagged variables (Table 2), indicating that $\mathrm{S} \_2$ and $\mathrm{S} \_0$ have no other determinants.

Table 2

Unit Root Tests

\begin{tabular}{cccccccc}
\hline S_2 & & & & & & & \\
\hline D-lag & t-adf & beta Y_1 & sigma & t-DY_lag & t-prob & AIC & F-prob \\
3 & $-4.8720^{* * *}$ & 0.5478 & 0.0053 & 0.2980 & 0.7663 & -10.40 & \\
2 & $-4.9010^{* * * *}$ & 0.5518 & 0.0052 & -1.6840 & 0.0953 & -10.42 & 0.7663 \\
1 & $-5.4630^{* * *}$ & 0.5126 & 0.0053 & -0.4266 & 0.6705 & -10.41 & 0.2396 \\
0 & $-6.2100^{* * *}$ & 0.4970 & 0.0053 & & & -10.42 & 0.3839 \\
\hline S_0 & & & & & & & \\
\hline D-lag & t-adf & beta Y_1 & sigma & t-DY_lag & t-prob & AIC & F-prob \\
3 & $-4.3680^{* * *}$ & 0.5232 & 0.0043 & -0.5038 & 0.6155 & -10.79 & \\
2 & $-4.7150^{* * *}$ & 0.5078 & 0.0043 & -0.7554 & 0.4517 & -10.81 & 0.6155 \\
1 & $-5.4220^{* * *}$ & 0.4778 & 0.0043 & 0.1885 & 0.8509 & -10.82 & 0.6646 \\
0 & $-6.1020^{* * *}$ & 0.4864 & 0.0043 & & & -10.84 & 0.8360 \\
\hline
\end{tabular}

Note. The table presents the ADF unit root tests (Dickey, D., \& Fuller, W. (1979). Distribution of the estimators for autoregressive time series with a unit root. Journal of the American Statistical Association, 74(366), 427-431. doi: 10.2307/2286348; Dickey, D., \& Fuller, W. (1981). Likelihood ratio statistics for autoregressive time series with a unit root. Econometrica, 49(4), 1057-1072. doi: 10.2307/1912517) for S_2 and S_0 of the Corwin, S. A., \& Schultz, P. (2012a). A simple way to estimate bid and ask spreads from daily high and low prices. The Journal of Finance, 67(2), 719-759. doi: 10.1111/j.1540-6261.2012.01729.x, model in the Brazilian stock market, showing constant, trend, and seasonal dummies (ADF tests $-\mathrm{T}=110$, Constant + Trend + Seasonals; $5 \%=-3.45,1 \%=-4.04)$. Source: The author. Statistical significance: $* * *-0.01$.

The unit root test results show another consequence. The possibility of endogeneity seems to be circumvented from the assumption that a stationary variable can be explained only by itself. This fact maintains the strong classical linear regression model assumptions and mitigates the possibility of bidirectional causality feedback (Asteriou \& Hall, 2011). Even for the cointegration analysis in the next section, the stationarity of $S_{-} 0$ and $S_{-} 2$ suggests that they are the driving force behind the control variables.

However, endogeneity is always a relevant issue because of biased estimates. We examine S_0 and S_2 individually in the unit root tests, but find no way to relate to another variable. Vector autoregressive models abandon the distinction between endogenous and exogenous variables and treat all variables as endogenous (Asteriou \& Hall, 2011). For long-run relationships, the variables in the model can form several equilibrium relationships governing the joint evolution of all variables (Asteriou \& Hall, 2011), making endogeneity an assumption of time-series analysis.

Stationarity results show that the studied measures are stable and can be forecasted (Bryman, 2012). This finding is consistent with Martins et al. (2013), who found that asymmetric information is an independent variable determining asset returns, and non-consistent with Martins and Paulo (2014), who found that asymmetric information is determined by risk, return, abnormal returns, liquidity, cost of equity, and size.

The finding is also consistent with Easley et al. (2002), who show the determination of asset returns by asymmetric information. 
The findings of Maskara and Mullineaux (2011) strengthen the stationarity finding, because they did not find any association between the Corwin and Schultz (2012a) and abnormal returns. Karstanje et al. (2013) considered S_2 and S_0 as proxies for liquidity and did not find the robust predictive ability of liquidity for forecasting asset returns, which is neutral related to stationarity finding, exactly as in Zhang et al. (2014).

Cerqueira and Pereira (2014) show the association between the Corwin-Schultz measure and quality of financial reporting in Europe. Their findings strengthen the power of the Corwin-Schultz measure as an asymmetric information measure, but go against the stationarity finding because poor quality of financial reporting generates asymmetric information.

Lin (2014) argues that the accuracy of the Corwin and Schultz (2012a) measure depends on the size of spread, transaction frequency, and degree of volatility. From Figures 1 and 2, the degree of volatility appears to imply a break in stability of measure, but the modelling process of S_2 and S_0 (see Tables 3 and 4 and Figures 3 and 4) results in the absence of strong structural breaks (Chow, 1960). Spread size and transaction frequency issues could be solved through aggregate data analysis.

Table 3

Modelling S_2 Using the OLS Method

\begin{tabular}{lccccc}
\cline { 2 - 6 } & Coefficient & Std. Error & t-value & t-prob & Part.R^2 \\
\hline S_2_1 & 0.5231 & 0.0754 & 6.9300 & $0.0000^{* * * *}$ & 0.3098 \\
Constant & -0.0037 & 0.0012 & -3.0600 & $0.0028^{* * * *}$ & 0.0806 \\
Seasonal_2 & -0.0010 & 0.0011 & -0.8510 & 0.3964 & 0.0067 \\
Trend & 0.0001 & 0.0023 & 5.0600 & $0.0000^{* * * *}$ & 0.1930 \\
\hline Sigma & 0.0053 & & RSS & & 0.3011 \\
$\mathrm{R}^{\wedge} 2$ & 0.7162 & & $\mathrm{~F}(3,107)$ & & $90.040[0.000]^{* * *}$ \\
Log-likelihood & 426.0730 & & $\mathrm{DW}$ & & 2.09 \\
$\mathrm{~N}^{\circ}$ of observations & 111 & & & $\mathrm{~N}^{\circ}$ of parameters & 4 \\
Mean (S_2) & 0.0061 & & $\operatorname{var}\left(\mathrm{S} \_2\right)$ & & $9.56201 \mathrm{e}-005$ \\
\hline
\end{tabular}

Note. The table presents the forecasting final model of S_2 computed using the single-equation dynamic modelling of Granger, C. W. J. (1981). Some properties of time series data and their use in econometric model specification. Journal of Econometrics, 16(1), 121-130. Retrieved from http://www.sciencedirect.com/science/article/pii/0304407681900798/part/first-page-pdf. doi: 10.1016/0304-4076(81)90079-8, for the Brazilian stock market.

Statistical significance: $* * *-0.01$. 
Table 4

Modelling S_0 by OLS

\begin{tabular}{|c|c|c|c|c|c|}
\hline & Coefficient & Std. Error & t-value & t-prob & Part.R^2 \\
\hline S_0_1 & 0.4638 & 0.0855 & 5.4200 & $0.0000 * * *$ & 0.2173 \\
\hline Constant & 0.0086 & 0.0014 & 5.9800 & $0.0000 * * *$ & 0.2520 \\
\hline Sigma & 0.0042 & & RSS & & 0.1901 \\
\hline $\mathrm{R}^{\wedge} 2$ & 0.2172 & & $\mathrm{~F}(1,106)$ & & $29.43[0.000]^{* * *}$ \\
\hline log-likelihood & 437.9030 & & DW & & 1.95 \\
\hline $\mathrm{N}^{\circ}$ of observations & 108 & & & $\mathrm{~N}^{\mathrm{o}}$ of parameters & 2 \\
\hline mean $\left(\mathrm{S} \_0\right)$ & 0.0161 & & $\operatorname{var}\left(S \_0\right)$ & & $2.2495 \mathrm{e}-5$ \\
\hline
\end{tabular}

Note. The table presents the forecasting final model of S_0 computed using single-equation dynamic modelling of Granger, C. W. J. (1981). Some properties of time series data and their use in econometric model specification. Journal of Econometrics, 16(1), 121-130. Retrieved from http://www.sciencedirect.com/science/article/pii/0304407681900798/part/first-page-pdf. doi: 10.1016/0304-4076(81)90079-8, for the Brazilian stock market.

Statistical significance: $* * *-0.01$.

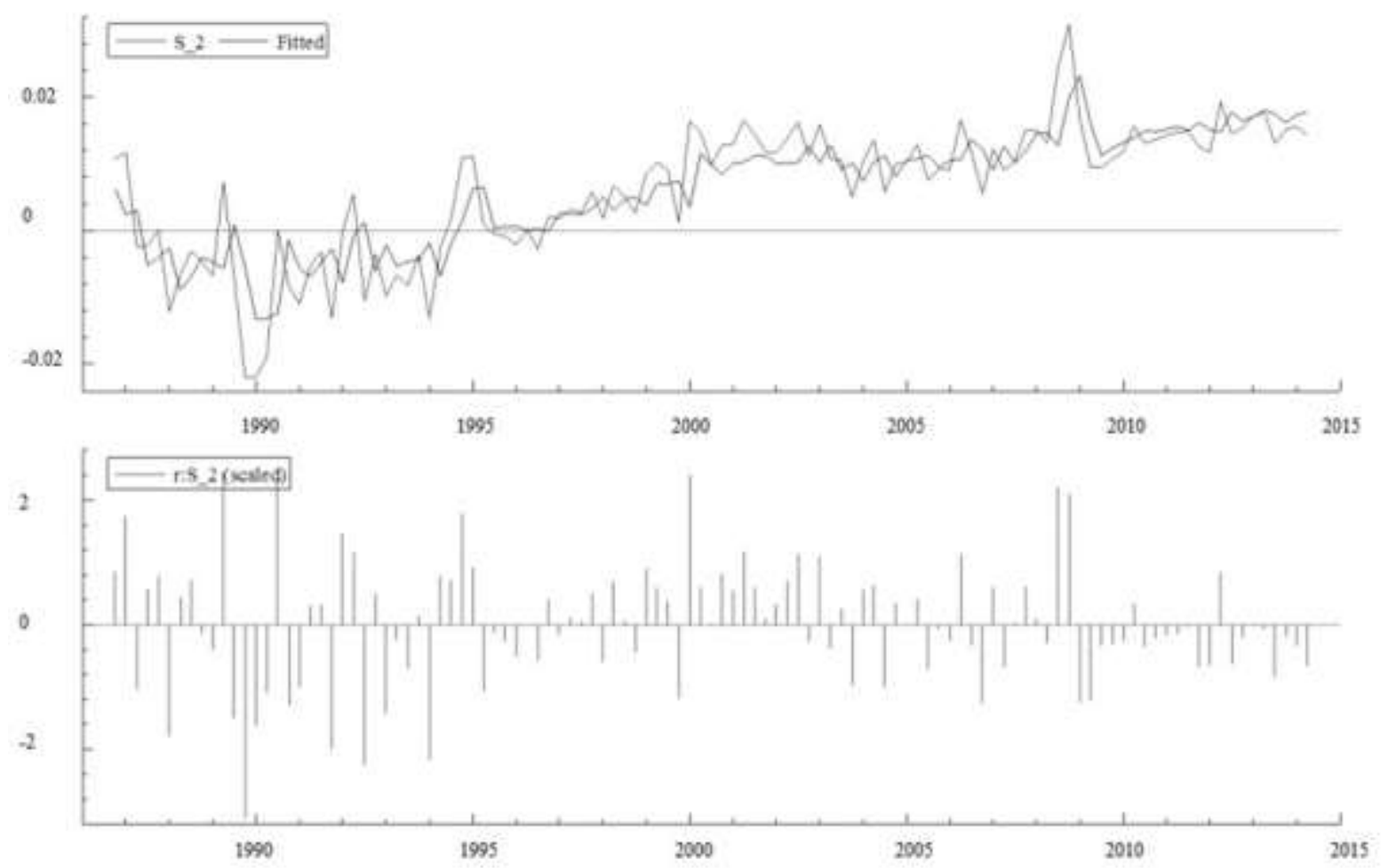

Figure 3. Fitted Values of $S \_2$

The figure presents the S_2 forecasting final model's fitted values computed by ordinary least squares in the Brazilian stock market. The lower part of figure shows the model residuals. Source: The author. 

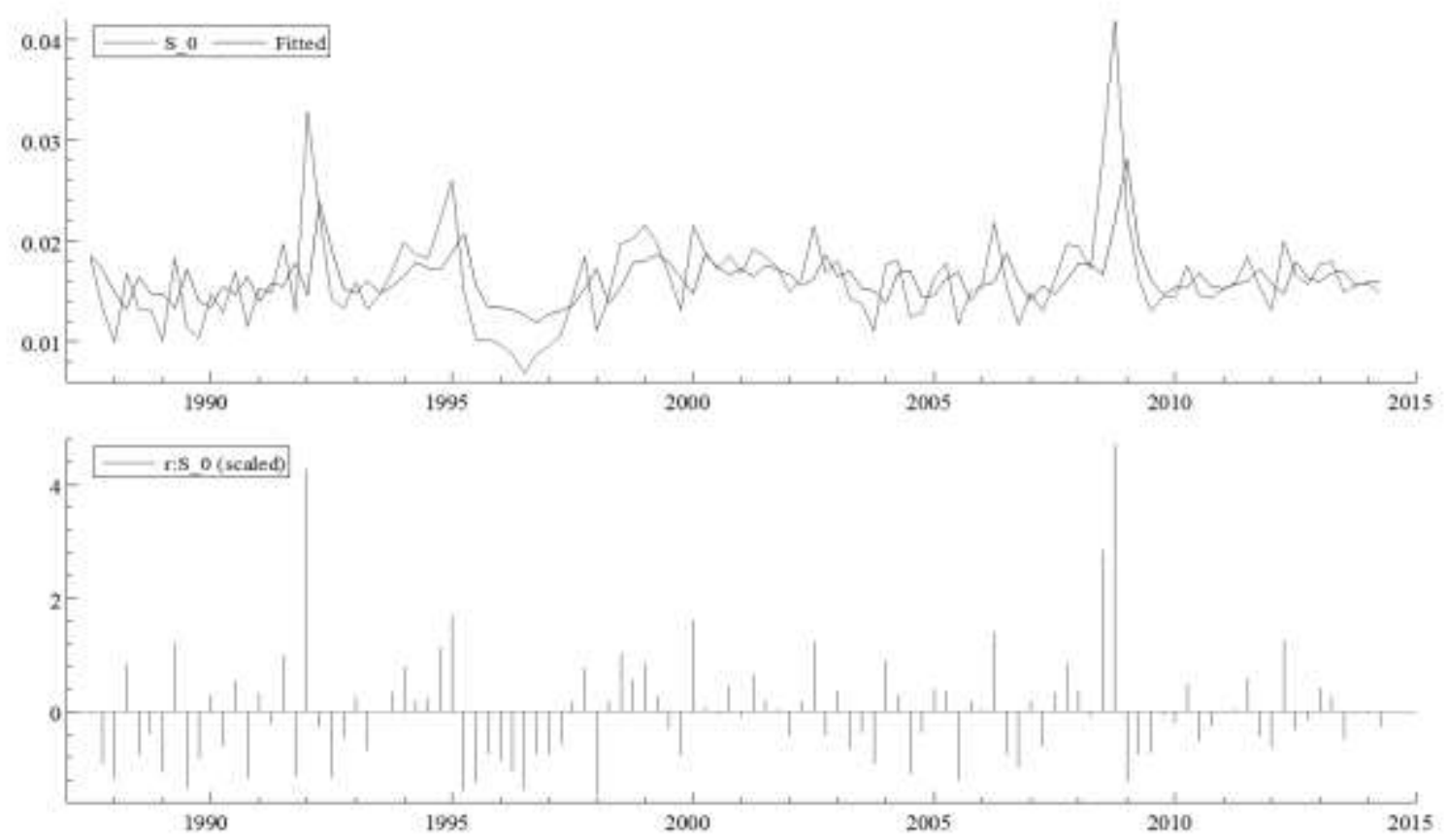

Figure 4. Fitted Values of S_0

The figure presents the S_0 forecasting final model's fitted values computed by ordinary least squares and in the Brazilian stock market. The lower part of figure shows the model residuals. Source: The author.

The forecasting of S_2 and S_0 was carried out using the single-equation dynamic modelling of Granger (1981) and OLS estimation.

Model selection has shown that the optimum specification belongs to the model with lagged variables in one period (Tables 3 and 4).

The S_0 forecasting process used only a constant and lagged variable, whereas the S_2 model was specified with a trend. Goodness of fit can be checked in Figures 3 and 4.

Therefore, on an aggregate basis, we can expect variance of asymmetric information in the Brazilian stock market. The prediction of asymmetric information is a novelty because other authors have not examined it in this manner (Girão, Martins, \& Paulo, 2014; Martins \& Paulo, 2013, 2014; Minardi et al., 2006).

The forecasting of asymmetric information is consistent with the theoretical framework. It shows a feasible asset mispricing (Akerlof, 1970) and helps uninformed traders obtain better information (Spence, 1973) besides abnormal returns, and diminish the consequences of private information trading on their portfolios.

\section{Robustness check}

A segregation of time subsamples (Table 5) shows that the average of S_2 increased following the Brazilian stock market reform, which introduced four different share listing segments (Rabelo \& Vasconcelos, 2002). This finding in a non-consistent sense represents stock market development theory (Demirgüc-Kunt \& Maksimovic, 1996; Demirgüc-Kunt, Feyen, \& Levine, 2013). Variable S_2 also became closer to a non-negative measure. The mean of S_O presented a peak in 2008-2009, consistent with the financial crisis. The exchange-rate regime is seen to have become flexible in 1999, which could be strongly related to the S_2 figures, with averages roughly half of the 2000-2007 mean figures. Political variables also can explain such asymmetric information movements. The Table 6 shows the measures by listing segments. 
Table 5

Subsamples of $S \_2$ and $S \_0$

\begin{tabular}{|c|c|c|c|c|c|}
\hline \multirow{3}{*}{ Subsample } & \multirow[b]{3}{*}{ N. Obs. } & \multirow{2}{*}{\multicolumn{4}{|c|}{ S_2 }} \\
\hline & & & & & \\
\hline & & Min. & Mean & Max. & Std. Dev. \\
\hline 1986:1-1989:4 & 16 & -.0220 & .0021 & .0293 & .0136 \\
\hline 1990:1-1994:2 & 18 & -.0218 & -.0074 & .0054 & .0068 \\
\hline 1994:3-1997:4 & 14 & -.0027 & .0024 & .0111 & .0042 \\
\hline 1998:1-1999:4 & 8 & .0012 & .0056 & .0102 & .0034 \\
\hline 2000:1-2007:4 & 32 & .0050 & .0116 & .0165 & .0031 \\
\hline 2008:1-2009:4 & 8 & .0094 & .0162 & .0308 & .0077 \\
\hline \multirow{2}{*}{ 2010:1-2014:2 } & 18 & .0117 & .0147 & .0192 & .0019 \\
\hline & & \multicolumn{4}{|c|}{ S_0 } \\
\hline Subsample & N. Obs. & Min. & Mean & Max. & Std. Dev. \\
\hline 1986:1-1989:4 & 16 & .0098 & .0191 & .0363 & .0087 \\
\hline 1990:1-1994:2 & 18 & .0114 & .0167 & .0327 & .0049 \\
\hline 1994:3-1997:4 & 14 & .0068 & .0134 & .0260 & .0057 \\
\hline 1998:1-1999:4 & 8 & .0110 & .0170 & .0215 & .0038 \\
\hline 2000:1-2007:4 & 32 & .0110 & .0163 & .0218 & .0028 \\
\hline 2008:1-2009:4 & 8 & .0130 & .0216 & .0419 & .0096 \\
\hline 2010:1-2014:2 & 18 & .0130 & .0159 & .0199 & .0017 \\
\hline
\end{tabular}

Note. The table presents the S_2 and S_0 estimates for the Brazilian stock market from 1986 to 2014 in seven periods. The figures show evidence of eventual structural break due to financial crisis. Source: The author.

Table 6

Subsamples of Firm Level S_2 and S_0 Estimates by Listing Segments

\begin{tabular}{|c|c|c|c|c|c|}
\hline \multirow{3}{*}{ Subsample } & \multirow[b]{3}{*}{ N. Obs. } & \multirow{2}{*}{\multicolumn{4}{|c|}{ S_2 }} \\
\hline & & & & & \\
\hline & & Min. & Mean & Max. & Std. Dev. \\
\hline Bovespa & 873 & -.0194 & .0054 & .0306 & .0072 \\
\hline N1 & 1843 & -.0218 & .0061 & .0647 & .0075 \\
\hline $\mathrm{N} 2$ & 92 & .0005 & .0115 & .0301 & .0053 \\
\hline \multirow[t]{2}{*}{ NM } & 1409 & -.0159 & .0095 & .0542 & .0066 \\
\hline & & \multicolumn{4}{|c|}{ S_0 } \\
\hline Subsample & N. Obs. & Min. & Mean & Max. & Std. Dev. \\
\hline Bovespa & 873 & .0000 & .0118 & .0502 & .0074 \\
\hline N1 & 1843 & .0000 & .0131 & .0680 & .0071 \\
\hline $\mathrm{N} 2$ & 92 & .0055 & .0160 & .0447 & .0061 \\
\hline NM & 1409 & .0000 & .0141 & .0542 & .0075 \\
\hline
\end{tabular}

Note. The table presents the S_2 and S_0 estimates for the Brazilian stock market from 1986 to 2014 in four listing segments. Source: The author. 
The presence of various listing segments in the Brazilian stock market obliges the adoption of improved information disclosure methods and the protection of minority shareholders (Rabelo \& Vasconcelos, 2002). The traditional segment (Bovespa) is expected to provide more asymmetric information compared to the new segment (NM). However, this hypothesis has not been confirmed. The averages of S_2 and S_0 for the traditional segment were higher than those for the NM segment.

The real estate industry presented a significantly higher (twice) average of asymmetric information (S_2), and textiles presented about half the full sample average of S_0 (Table 7).

Table 7

Subsamples of Firm Level S_2 and S_0 Estimates by Industry

\begin{tabular}{|c|c|c|c|c|c|}
\hline & \multirow{2}{*}{\multicolumn{4}{|c|}{ S_2 }} \\
\hline \multirow[b]{2}{*}{ Subsample } & \multirow[b]{2}{*}{ N. Obs. } & & & & \\
\hline & & Min. & Mean & Max. & Std. Dev. \\
\hline Food and Beverage & 266 & -.0104 & .0070 & .0542 & .0077 \\
\hline Retail & 293 & -.0156 & .0064 & .0306 & .0065 \\
\hline Real Estate & 256 & -.0053 & .0122 & .0333 & .0068 \\
\hline Utilities & 690 & -.0194 & .0092 & .0285 & .0065 \\
\hline Bank and Insurance & 494 & -.0159 & .0051 & .0647 & .0076 \\
\hline Mining & 260 & -.0125 & .0049 & .0343 & .0074 \\
\hline Other & 555 & -.0142 & .0078 & .0314 & .0067 \\
\hline Paper & 135 & -.0171 & .0049 & .0392 & .0084 \\
\hline Oil and Gas & 228 & -.0190 & .0060 & .0286 & .0073 \\
\hline Chemical & 138 & -.0159 & .0051 & .0259 & .0076 \\
\hline Steel & 392 & -.0218 & .0058 & .0252 & .0072 \\
\hline Technology & 21 & .0042 & .0086 & .0140 & .0020 \\
\hline Telecommunication & 202 & -.0152 & .0074 & .0379 & .0072 \\
\hline Textiles & 57 & -.0079 & .0050 & .0225 & .0067 \\
\hline Logistics & 152 & -.0100 & .0089 & .0301 & .0066 \\
\hline \multirow[t]{2}{*}{ Automobiles } & 78 & -.0139 & .0084 & .0227 & .0065 \\
\hline & & \multicolumn{4}{|c|}{ S_0 } \\
\hline Subsample & N. Obs. & Min. & Mean & Max. & Std. Dev. \\
\hline Food and Beverage & 266 & .0000 & .0105 & .0542 & .0089 \\
\hline Retail & 293 & .0000 & .0106 & .0432 & .0072 \\
\hline Real Estate & 256 & .0000 & .0182 & .0505 & .0081 \\
\hline Utilities & 690 & .0000 & .0158 & .0611 & .0067 \\
\hline Bank and Insurance & 494 & .0010 & .0122 & .0680 & .0063 \\
\hline Mining & 260 & .0000 & .0121 & .0443 & .0081 \\
\hline Other & 555 & .0000 & .0131 & .0433 & .0057 \\
\hline Paper & 135 & .0007 & .0107 & .0463 & .0068 \\
\hline
\end{tabular}


Table 7 (continued)

\begin{tabular}{lccccc} 
& & \multicolumn{3}{c}{ S_0 } \\
\cline { 3 - 6 } Subsample & N. Obs. & Min. & Mean & Max. & Std. Dev. \\
\cline { 3 - 6 } Oil and Gas & 228 & .0004 & .0142 & .0418 & .0076 \\
Chemical & 138 & .0000 & .0124 & .0351 & .0070 \\
Steel & 392 & .0000 & .0128 & .0420 & .0068 \\
Technology & 21 & .0077 & .0117 & .0169 & .0025 \\
Telecommunication & 202 & .0000 & .0142 & .0475 & .0069 \\
Textiles & 57 & .0000 & .0078 & .0247 & .0077 \\
Logistics & 152 & .0000 & .0127 & .0447 & .0076 \\
Automobiles & 78 & .0000 & .0124 & .0350 & .0073 \\
\hline
\end{tabular}

Note: The table presents the $S \_2$ and S_0 estimates for the Brazilian stock market from 1986 to 2014 by industry. Source: The author.

The daily average of $\mathrm{S} \_0$ is quite similar for the Bovespa and NM segments $(0.050$ and 0.054 respectively), suggesting that negative values had a huge influence on the average of S_2. The negative values were from the period prior to 1994, as shown in Figure 1.

The variables representing the growth opportunity set, leverage, size, and returns have been standard in the financial literature, because they represent the characteristics that really differentiate companies (Demirgüc-Kunt et al., 2013; Titman \& Wessels, 1988). The descriptive statistics of M/B, D/E, SIZE, and RETURN are shown in Table 8. Note that variable size has no observations for the second quarter of 1986 and it does not change the statistical sense or significance of the cointegration results.

Table 8

Descriptive Statistics of Variables Related to Asymmetric Information

\begin{tabular}{lccccc}
\hline Variable & N. Obs. & Min. & Mean & Max. & Std. Dev. \\
\hline M/B & 111 & .0000 & 4.5154 & 108.7100 & 14.2290 \\
D/E & 111 & .0000 & 0.4627 & 6.0384 & 0.7400 \\
SIZE & 110 & 12.5510 & 18.5630 & 21.2370 & 2.0885 \\
RETURN & 111 & -0.4030 & 0.0481 & 0.6356 & 0.2175 \\
\hline
\end{tabular}

Note. The table presents the descriptive statistics of the variables' aggregate data that could be related to asymmetric information, such as the growth opportunity set, leverage, size, and stock return for the Brazilian stock market from 1986 to 2014. Source: The author.

Cointegration analysis (Table 9) shows that asymmetric information has a long-run relationship with M/B, D/E, SIZE, and RETURN. This result is consistent with the prediction that these variables discriminate between companies. Time-varying cointegration also shows that the vectors vary in different periods. 
Table 9

Time-varying Cointegration Equation of Asymmetric Information

\begin{tabular}{|c|c|c|c|c|}
\hline & S_2 & & S_0 & \\
\hline \multicolumn{5}{|l|}{ VECM } \\
\hline $\mathrm{M} / \mathrm{B}$ & -0.0022 & & -0.0029 & \\
\hline $\mathrm{D} / \mathrm{E}$ & 0.0821 & & 0.1012 & \\
\hline SIZE & 0.0045 & & 0.0053 & \\
\hline RETURN & -0.0715 & & -0.0888 & \\
\hline $\mathrm{p}$ & 1 & & 1 & \\
\hline $\mathrm{r}$ & 1 & & 1 & \\
\hline \#OBS & 114 & & 114 & \\
\hline TV VECM & LRtvc & p-value & LRtvc & $\mathrm{p}$-value \\
\hline $\mathrm{m}=1$ & 3.0500 & 0.6924 & 5.2000 & 0.3921 \\
\hline $\mathrm{m}=2$ & 11.4400 & 0.3239 & 16.7300 & 0.0806 \\
\hline $\mathrm{m}=3$ & 17.8400 & 0.2709 & 20.8700 & 0.1410 \\
\hline $\mathrm{m}=4$ & 43.8000 & 0.0016 & 47.1800 & 0.0005 \\
\hline $\mathrm{m}=5$ & 70.9400 & 0.0000 & 66.4800 & 0.0000 \\
\hline $\mathrm{m}=6$ & 87.8100 & 0.0000 & 82.6100 & 0.0000 \\
\hline $\mathrm{m}=7$ & 91.8900 & 0.0000 & 88.6200 & 0.0000 \\
\hline $\mathrm{m}=8$ & 100.9400 & 0.0000 & 93.4400 & 0.0000 \\
\hline $\mathrm{m}=9$ & 107.4600 & 0.0000 & 99.0400 & 0.0000 \\
\hline $\mathrm{m}=10$ & 113.5400 & 0.0000 & 114.9000 & 0.0000 \\
\hline $\mathrm{m}=11$ & 119.9800 & 0.0000 & 144.1100 & 0.0000 \\
\hline $\mathrm{m}=12$ & 130.2700 & 0.0000 & 165.2400 & 0.0000 \\
\hline $\mathrm{m}=13$ & 170.8300 & 0.0000 & 202.1800 & 0.0000 \\
\hline $\mathrm{m}=14$ & 245.3600 & 0.0000 & 279.1900 & 0.0000 \\
\hline$m=15$ & 302.7000 & 0.0000 & 338.4000 & 0.0000 \\
\hline
\end{tabular}

Note. The table presents the time-varying cointegration equation and tests (Bierens, H., \& Martins, L. (2010). Time-varying cointegration. Econometric Theory, 26(5), 1-38. doi: 10.1017/S0266466609990648) among S_2 and S_0 and variables representing the growth opportunity set, leverage, size, and stock returns in the Brazilian stock market from 1986 to 2014, where $p$ is the number of periods of optimal choice for lagged variables, $r$ is the number of ranks or cointegration equation, and $\mathrm{m}$ is the maximum number of polynomials of the Chebyshev time polynomials. Source: The author.

However, the sense of relationship has to be carefully considered. From Table 9, M/B and RETURN were negatively associated with asymmetric information. RETURN would be the reason of asymmetric information, but certainly the negative relationship is due to the extent of uninformed traders facing losses from asymmetric information (Grossman \& Stiglitz, 1980).

The growth opportunity set would be related to asymmetric information because it represents the younger companies, but the results show the opposite relationship. This indicates that asymmetric information is also present in more consolidated companies. This specific finding is consistent with Minardi et al. (2006) owing to liquidity issues. 


\section{Concluding Remarks}

The main implication of this paper is that the Corwin-Schultz measures are stationary, valid, and reliable. Thus, there is an easy method to compute asymmetric information in the Brazilian stock market. With a quarter in advance, one can forecast the behaviour of firm-level variables.

The subsamples of S_2 and S_0 show that industries can be more sensitive to asymmetric information, and that the average asymmetric information of the traditional segment can still be lower than that of other segments. This finding suggests a combined research between industry and segments on the real effects of different listing segments.

To test the financial and economic theories in developing markets, we need to develop S_2 and S_0 as measures of asymmetric information. For practical applications, S_2 and S_0 measures can help investment managers select stocks with higher asymmetric information as well as informed traders.

This study has some limitations. The Brazilian stock market has been changing during the last 15 years. Although the developing Brazilian market has around 500 listed companies, our sample considered only the 68 companies with the most traded shares. Furthermore, we considered Corwin and Schultz's (2012a) allegation that the actual high and low prices of infrequently traded stocks were not observed. The choice of this sample is based only on the actual level of asymmetric information in the Brazilian stock market. We tried to address the Ibovespa methodological changes with some eventual adjustments, survival bias, and so on, but mainly sought a measure to represent asymmetric information for other studies.

Unit root and cointegration methods are time-series techniques. The results were compared with the asymmetric information measure standard in the literature. Therefore, researchers need to address other markets, techniques, and measures to improve the robustness of the Corwin-Schultz measures. We conjecture that the Corwin-Schultz measure would be reliable only if it were similar to the PIN score, thus allowing for generalization and replication of the study.

\section{References}

Agarwal, P., \& OHara, M. (2006). Information risk and capital structure [Working Paper]. Social Science Research Network, Rochester, NY.

Akerlof, G. A. (1970). The market for "lemons": quality uncertainty and the market mechanism. The Quarterly Journal of Economics, 84(3), 488-500. Retrieved from http://www.jstor.org/stable/1879431

Asteriou, D., \& Hall, S. (2011). Applied econometrics (2nd ed.). Hampshire: Palgrave Macmillan.

Bailey, R. (2005). The economics of financial markets. Cambridge: Cambridge University Press.

Bierens, H., \& Martins, L. (2010). Time-varying cointegration. Econometric Theory, 26(5), 1-38. doi: $10.1017 / \mathrm{S} 0266466609990648$

Blume, L., Easley, D., \& O Hara, M. (1994). Market statistics and technical analysis: the role of volume. The Journal of Finance, 49(1), 153-181. Retrieved from http://www.jstor.org/stable/2329139. doi: $10.2307 / 2329139$

Bryman, A. (2012). Social research methods (4th ed.). Oxford: University Press. 
Cerqueira, A., \& Pereira, C. (2014). Financial reporting quality and information asymmetry in Europe. British Accounting Review, 32-51. Retrieved from http://icfb.rs.opf.slu.cz/sites/icfb.rs.opf.slu.cz/files/04_cerqueira.pdf

Chan, K., Menkveld, A. J., \& Yang, Z. (2008). Information asymmetry and asset prices: evidence from the China foreign share discount. The Journal of Finance, 63(1), 159-196. Retrieved from http://www.jstor.org/stable/25094437. doi: 10.1111/j.1540-6261.2008.01313.x

Chow, G. (1960). Tests of equality between sets of coefficients in two linear regressions. Econometrica, 28(3), 591-605. doi: 10.2307/1910133

Corwin, S. A., \& Schultz, P. (2012a). A simple way to estimate bid and ask spreads from daily high and low prices. The Journal of Finance, 67(2), 719-759. Retrieved from http://iawltxhtml.ivowelch.info/sample-fame-3/cs.pdf. doi: 10.1111/j.1540-6261.2012.01729.x

Corwin, S. A., \& Schultz, P. (2012b). Internet appendix for "A simple way to estimate bid-ask spreads from daily high and low prices". The Journal of Finance, 67(2), 719-759. Retrieved from https://www3.nd.edu/ scorwin/documents/high-low_spreads_InternetAppendix_002.pdf

Cronbach, L., \& Shavelson, R. (2004). My current thoughts on coefficient alpha and successor procedures. Educational and Psychological Measurement, 64(3), 391-418. doi: $10.1177 / 0013164404266386$

Cuthbertson, K., \& Nitzche, D. (2004). Quantitative financial economics: stocks, bonds and foreign exchange (2nd ed.). Chichester: John Wiley \& Sons.

Demirgüc-Kunt, A., \& Maksimovic, V. (1996). Stock market development and financing choices of firms. The World Bank Economic Review, 10(2), 341-369. Retrieved from http://www.jstor.org/stable/3990066?seq=1\#page_scan_tab_contents. 10.1093/wber/10.2.341

Demirgüc-Kunt, A., Feyen, E., \& Levine, R. (2013). The evolving importance of banks and securities markets. The World Bank Economic Review, 27(3), 476-490. doi:10.1093/wber/lhs022

Dickey, D., \& Fuller, W. (1979). Distribution of the estimators for autoregressive time series with a unit root. Journal of the American Statistical Association, 74(366), 427-431. doi: 10.2307/2286348

Dickey, D., \& Fuller, W. (1981). Likelihood ratio statistics for autoregressive time series with a unit root. Econometrica, 49(4), 1057-1072. doi: 10.2307/1912517

Dufour, A., \& Engle, R. F. (2000). Time and the price impact of a trade. The Journal of Finance, 55(6), 2467-2498. Retrieved from http://www.jstor.org/stable/222391. doi: 10.1111/0022-1082.00297

Easley, D., \& O’Hara, M. (1991). Order form and information in securities markets. The Journal of Finance, 46(3), 905-927. Retrieved from http://www.jstor.org/stable/2328548. doi: $10.2307 / 2328548$

Easley, D., \& O'Hara, M. (1992). Time and the process of security price adjustment. The Journal of Finance, 47(2), 577-605. Retrieved from http://www.jstor.org/stable/2329116. doi: $10.2307 / 2329116$

Easley, D., \& O’Hara, M. (2004). Information and cost of capital. The Journal of Finance, 59(4), 15531583. Retrieved from http://www.jstor.org/stable/3694871. doi: 10.1111/j.15406261.2004.00672.x

Easley, D., Hvidkjaer, S., \& O'Hara, M. (2002). Is information risk a determinant of asset returns? The Journal of Finance, 57(5), 2185-2221. Retrieved from http://www.jstor.org/stable/3094509. doi: $10.1111 / 1540-6261.00493$ 
Easley, D., Kiefer, N., \& O'Hara, M. (1997). One day in the life of a very common stock. The Review of Financial Studies, 10(3), 805-835. Retrieved from http://www.jstor.org/stable/2962204

Easley, D., Kiefer, N. M., O'Hara, M., \& Paperman, J. B. (1996). Liquidity, information, and infrequently traded stocks. The Journal of Finance, 51(4), 1405-1436. Retrieved from http://www.jstor.org/stable/2329399. doi: 10.2307/2329399

Easley, D., O’Hara, M., \& Srinivas, P. (1998). Option volume and stock prices: evidences on where informed traders trade. The Journal of Finance, 53(2), 431-465. Retrieved from http://www.jstor.org/stable/117358. doi: 10.1111/0022-1082.194060

French, K., \& Roll, R. (1986). Stock return variances: the arrival of information and the reaction of traders. The Journal of Financial Economics, 17(1), 5-26. Retrieved from http://www.sciencedirect.com/science/article/B6VBX-458WN9H-

H/2/44fd7882c954da27b9afcbdbbca674c6. doi: 10.1016/0304-405X(86)90004-8

Girão, L., Martins, O., \& Paulo, E. (2014). Avaliação de empresas e probabilidade de negociação com informação privilegiada no mercado brasileiro de capitais. Revista de Administração, 49(3), 462 475. doi: 10.5700/rausp1161

Glosten, L. R., \& Harris, L. E. (1988). Estimating the components of bid/ask spread. Journal of Financial Economics, 21(1), 123-142. Retrieved from http://www.sciencedirect.com/science/article/pii/0304405X88900347. doi: 10.1016/0304405X(88)90034-7

Glosten, L. R., \& Milgron, P. (1985). Bid, ask and transaction prices in a specialist market with heterogeneously informed traders. Journal of Financial Economics, 14(1), 71-100. Retrieved from

https://www.researchgate.net/publication/222462417_Bid_Ask_and_Transaction_Prices_in_a_ Specialist_Market_With_Heterogeneously_Informed_Traders. doi: $\quad$ 10.1016/0304405X(85)90044-3

Granger, C. W. J. (1981). Some properties of time series data and their use in econometric model specification. Journal of Econometrics, 16(1), 121-130. Retrieved from http://www.sciencedirect.com/science/article/pii/0304407681900798/part/first-page-pdf. doi: 10.1016/0304-4076(81)90079-8

Granger, C. W. J. (2010). Some thoughts on the development of cointegration. Journal of Econometrics, 158(2010), 3-6. doi: 10.1016/j.jeconom.2010.03.002

Grossman, S., \& Stiglitz, J. (1980). On the impossibility of informationally efficient markets. The American Economic Review, 70(3), 393-408. Retrieved from http://www.jstor.org/stable/1805228

Gu, F., Little, T., \& Kingston, N. (2013). Misestimation of reliability using coefficient alpha and structural equation modeling when assumptions of Tau-equivalence and uncorrelated errors are violated. Methodology: European Journal of Research Methods for the Behavioral and Social Sciences, 9(1), 30-40. doi: 10.1027/1614-2241/a000052

Harris, L. (1990). Statistical properties of the Roll serial covariance bid/ask estimator. The Journal of Finance, 45(2), 579-590. Retrieved from http://www.jstor.org/stable/2328671. doi: $10.2307 / 2328671$

Hasbrouck, J. (1988). Trades, quotes, inventories, and information. Journal of Financial Economics, $22(2)$, 229-252.

Retrieved

from http://www.sciencedirect.com/science/article/pii/0304405X88900700. doi: 10.1016/0304405X(88)90070-0 
Hasbrouck, J. (1991). Measuring the information content of stock trades. The Journal of Finance, 46(1), 179-207. Retrieved from http://www.jstor.org/stable/2328693. doi: 10.2307/2328693

Hasbrouck, J. (1996). Order characteristics and stock price evolution: an application to program trading. Journal of Financial Economics, 41(1), 129-149. Retrieved from http://www.sciencedirect.com/science/article/pii/0304405X9500858C. doi: 10.1016/0304405X(95)00858-C

Hasbrouck, J. (1999). Security bid/ask dynamics with discreteness and clustering: simple strategies for modeling and estimation. Journal of Financial Markets, 2(1), 1-28. Retrieved from http://www.sciencedirect.com/science/article/pii/S1386418198000081. doi: 10.1016/S13864181(98)00008-1

Hasbrouck, J. (2007). Empirical market microstructure: the institutions, economics, and econometrics of securities trading. New York: Oxford University Press.

Hasbrouck, J., \& Saar, G. (2009). Technology and liquidity provision: the blurring of traditional definitions. Journal of Financial Markets, 12(2009), 143-172. doi: 10.1016/j.finmar.2008.06.002

Hasbrouck, J., \& Saar, G. (2013). Low-latency trading. Journal of Financial Markets, 16(4), 646-679. doi: 10.1016/j.finmar.2013.05.003

Hasbrouck, J., \& Seppi, D. J. (2001). Common factors in prices, order flows, and liquidity. Journal of Financial Economics, 59(3), 383-411. Retrieved from http://www.sciencedirect.com/science/article/pii/S0304405X0000091X. doi: 10.1016/S0304405X(00)00091-X

Huang, R., \& Stoll, H. (1997). The components of the bid-ask spread: a general approach. Review of Financial Studies, 10(4), 995-1034. doi:10.1093/rfs/10.4.995

Karstanje, D., Sojli, E., Tham, W. W., \& Wel, M. van der (2013). Economic valuation of liquidity timing. Journal of Banking \& Finance, 37(12), 5073-5087. doi: 10.1016/j.jbankfin.2013.09.010

Krinsky, I., \& Lee, J. (1996). Earnings announcements and the components of the bid-ask spread. The Journal of Finance, 51(4), 1523-1535. doi: 10.1111/j.1540-6261.1996.tb04078.x

Lee, C., \& Ready, M. (1991). Inferring trade direction from intraday data. The Journal of Finance, 46(2), 733-746. doi: $10.2307 / 2328845$

Lin, C.-C. (2014). Estimation accuracy of high-low spread estimator. Finance Research Letters, 11(1), 54-62. doi: 10.1016/j.frl.2013.05.004

Madhavan, A. (2000). Market microstructure: a survey. Journal of Financial Markets, 3(3), 205-258. Retrieved from http://www.sciencedirect.com/science/article/pii/S1386418100000070. doi: 10.1016/S1386-4181(00)00007-0

Martins, O. S., \& Paulo, E. (2013). A probabilidade de negociação com informação privilegiada no mercado acionário brasileiro. Revista Brasileira de Finanças, 11(2), 249-280. Retrieved from http://bibliotecadigital.fgv.br/ojs/index.php/rbfin/article/view/6233/8427

Martins, O. S., \& Paulo, E. (2014). Assimetria de informação na negociação de ações, características econômico-financeiras e governança corporativa no mercado acionário brasileiro. Revista Contabilidade e Finanças, 25(64), 33-45. doi: 10.1590/S1519-70772014000100004

Martins, O. S., Paulo, E., \& Albuquerque, P. H. M. (2013). Negociação com informação privilegiada e retorno das ações na BM\&FBOVESPA. Revista de Administração de Empresas, 53(4), 350-362. Retrieved from http://rae.fgv.br/sites/rae.fgv.br/files/artigos/10.1590-00347590201300400003.pdf. doi: 10.1590/S0034-75902013000400003 
Maskara, P. K., \& Mullineaux, D. J. (2011). Information asymmetry and self-selection bias in bank loan announcement studies. Journal of Financial Economics, 101(3), 684-694. doi: 10.1016/j.jfineco.2011.03.019

Minardi, A., Sanvicente, A., \& Monteiro, R. (2006). Bid-ask spreads in a stock exchange without market specialists. Latin American Business Review, 7(2), 19-39. doi: 10.1300/J140v07n02_02

Muth, J. (1961). Rational expectations and the theory of price movements. Econometrica, 29(3), 315335. doi: $10.2307 / 1909635$

O'Hara, M. (2003). Presidential address: liquidity and price discovery. The Journal of Finance, 58(4), 1335-1354. Retrieved from http://www.jstor.org/stable/3648213. doi: 10.1111/1540-6261.00569

Rabelo, F. M., \& Vasconcelos, F. C. (2002). Corporate governance in Brazil. Journal of Business Ethics, 37(3), 321-335. Retrieved from http://link.springer.com/article/10.1023/A\%3A1015249300794. doi: 10.1023/A:1015249300794

Roll, R. (1984). A simple implicit measure of the effective bid-ask spread in an efficient market. The Journal of Finance, 39(4), 1127-1139. Retrieved from http://www.jstor.org/stable/2327617. doi: $10.2307 / 2327617$

Roll, R., \& Subrahmanyam, A. (2010). Liquidity skewness. Journal of Banking and Finance, 34(10), 2562-2571. doi: 10.1016/j.jbankfin.2010.04.012

Roll, R., Schwartz, E., \& Subrahmanyan, A. (2014). Trading activity in the equity market and its contingent claims: an empirical investigation. Journal of Empirical Finance, 28, 13-35. doi: 10.1016/j.jempfin.2014.05.007

Rosser, J., Jr. (2003). A Nobel prize for asymmetric information: the economic contributions of George Akerlof, Michael Spence and Joseph Stiglitz. Review of Political Economy, 15(1), 3-21. doi: $10.1080 / 09538250308445$

Rothschild, M., \& Stiglitz, J. (1976). Equilibrium in competitive insurance markets: an essay on the economics of imperfect information. The Quarterly Journal of Economics, 90(4), 629-649. Retrieved from http://www.jstor.org/stable/1885326. doi: 10.2307/1885326

Spence, M. (1973). Job market signaling. The Quarterly Journal of Economics, 87(3), 355-374. Retrieved from http://www.jstor.org/stable/1882010

Timmermann, A. (1995). Cointegration tests of present value models with a time-varying discount factor. Journal of Applied Econometrics, 10(1), 17-31. Retrieved from http://www.jstor.org/stable/2284940

Titman, S., \& Wessels, R. (1988). The determinants of capital structure choice. The Journal of Finance, 43(1), 1-19. Retrieved from http://links.jstor.org/sici?sici=00221082\%28198803\%2943\%3A1\%3C1\%3ATDOCSC\%3E2.0.CO\%3B2-A. doi: 10.2307/2328319

Zhang, X., Yang, J., Su, H., \& Zhang, S. (2014). Liquidity premium and the Corwin-Schultz bid-ask spread estimate. China Finance Review International, 4(2), 168-186. doi: 10.1108/CFRI-092013-0121

\section{Author's Profile}

Alexandre Ripamonti

Rua Itapetininga, 34, Cidade Parquelandia, 08771-910, Mogi das Cruzes, SP, Brazil. E-mail address: alexandre@ arpc.com.br; ripamonti@usp.br 